\title{
High-rise construction as a method for architectural development of megapolises
}

\author{
Vadim Kankhva ${ }^{1, *}$ \\ ${ }^{1}$ Moscow State University of Civil Engineering, Yaroslavskoye shosse 26, Moscow, 129337, Russia
}

\begin{abstract}
The article analyzes the current state of urban development in Moscow, there are revealed the insights into pattern of large investment projects. The regulatory framework as well as the state and the forecast of housing funds are scrutinized. A number of problems, that are related to the implementation of high-rise construction projects at all stages of the life cycles, are highlighted by the example of unique facilities, which are under construction or have already been built. Substantiation of high-rise construction by the transport hubs in megapolises is given. There are also considered main advantages of Moscow renovation project and criticism against it.
\end{abstract}

\section{Introduction}

Urban development of Moscow is one of the core activity areas of the construction complex of the capital. Comprehensive development is carried out in close interdependence between authorities and city investors with account of the town planning strategy. High capital intensity of urban planning investment projects as well as variability of decisions on territory development require a thorough evaluation, both from the point of view of the government policy in terms of urban development and economic efficiency of utilization of budgetary funds of Moscow [1].

In itself, the economic evaluation of investment projects involving the city budget cannot be representative, since participation in such projects is not due to the commercial interest of state structures, but to the fulfillment of obligations to the citizens.

\section{Materials and Methods}

Investment activity is given special attention in the legislation of the Russian Federation. In addition to determining the basic concepts of investment activity, the legislation also defines subjects of investment activity (investors, customers, contractors, users of capital investment objects and other persons). The subject of investment activity has the right to combine the functions of two or more entities, unless otherwise is stipulated by the contract and (or) the government contract, which is concluded between them.

\footnotetext{
* Corresponding author: vskanhva@mail.ru
} 
Russian legislation considers a high-rise structure to be one that extends higher than $75 \mathrm{~m}$ from the lower planning level, where the road mark for fire trucks is, to the lower level of the opening in the outer wall of the upper floor.

Examples of such facilities are the Moscow International Business Center "Moscow City" and a number of multifunctional high-rise residential complexes. Meantime there are already built such objects as (Figure 1):

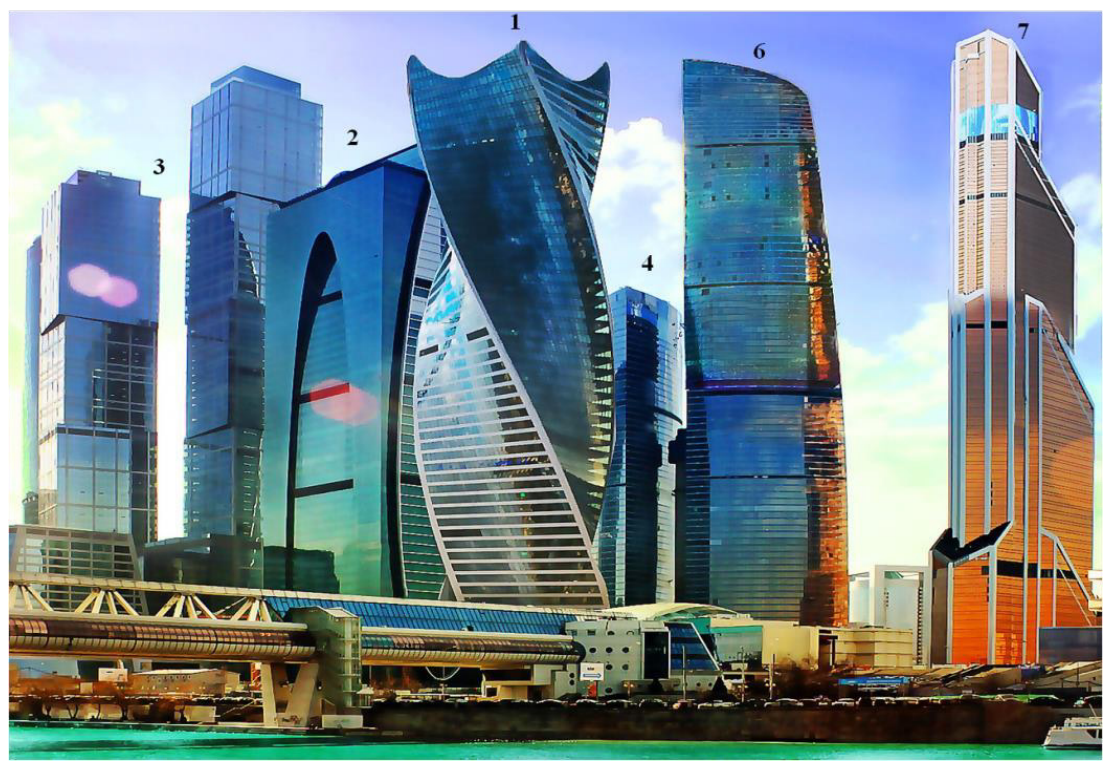

Fig. 1. Moscow International Business Center "Moscow City"

1. "Evolution Tower" is a multifunctional center with a height of 54 floors (255 meters), which includes commercial premises with restaurants, as well as office premises.

2. "Imepria Tower" is a business complex with a height of 60 floors (239 meters), which is a multifunctional complex that combines office space, apartments and commercial premises.

3. "City of capitals" is an architectural ensemble, symbolizing Moscow and St. Petersburg. It combines the entertainment complex, offices and luxury apartments. It consists of two towers - a 76-story Moscow and a 65-story St. Petersburg, $302 \mathrm{~m}$ high and $257 \mathrm{~m}$ high, respectively, combined with a 17-storey stylobation and a 17-story domed building with an atrium. The entire complex is located on a single podium, consisting of a 6-level underground volume and above-ground 4-level public space.

4. "Embankment Tower" is a complex intended for office premises of "A" class and includes three buildings of different number of storeys (17, 27 and 59 storeys). The common areas, located on the first level, and the trade hall unite them into a single whole.

5. "Eurasia Tower" is an office and recreational complex, comprising a 309-meter building with a total area of $207,542 \mathrm{~m}^{2}$ on a three-storey podium, which houses a fitness center, entertainment centers, restaurants and shops.

6. "Federation Tower" is an office complex consisting of two triangular towers, 374 and $242 \mathrm{~m}$ high, respectively, located on a stylobation. There are located office space and apartments, separated by technical floors. There is also a restaurant.

7. "Mercury City Tower" is a multifunctional building with premises of residential and non-residential funds, premises for retail and cultural purposes with three underground floors.

Examples of high-rise construction of multifunctional housing estates are (Figure 2): 
1. "Triumph Palace" is a housing estate with the height of $264.1 \mathrm{~m}$.

2. "Mosfilm Tower" is a housing estate with a height of $208 \mathrm{~m}$.

3. "Tricolor" is a housing estate with height of $194 \mathrm{~m}$.

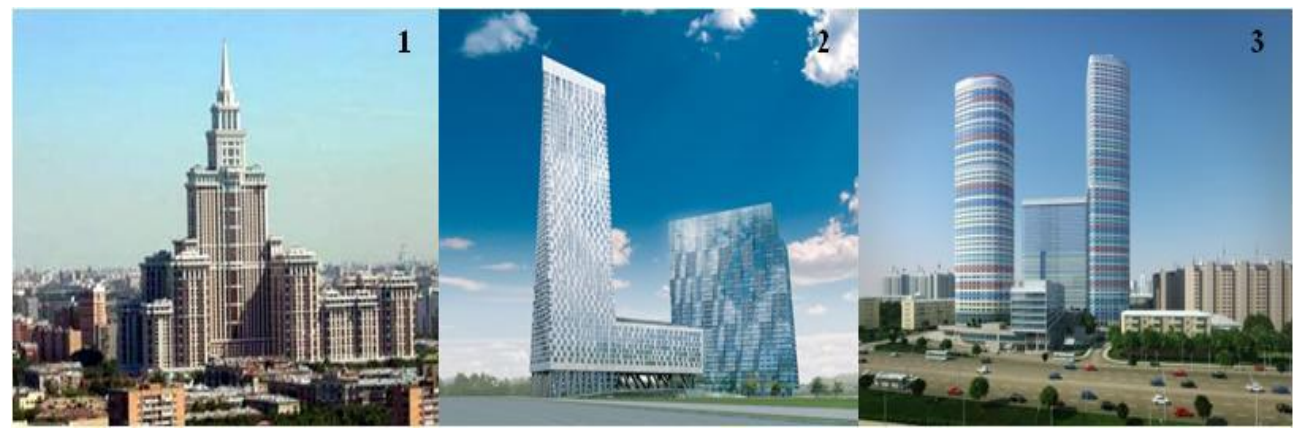

Fig. 1. Moscow multifunctional housing estates

The investment project does not necessarily require capital construction, since investments can be made in the growth of working assets, or the investor can contribute to the project a finished building or existing equipment. Significantly, investment projects, usually, are indivisible and not replicable. It is important to note that investment projects, in a certain sense, are unique. This is manifested in the fact that any project is oriented towards the use of new knowledge about nature, technosphere and society, as well as a certain combination of available resources, that are absent in the market for the purpose to carve out a certain business segment and capitalize on it [2, 3].
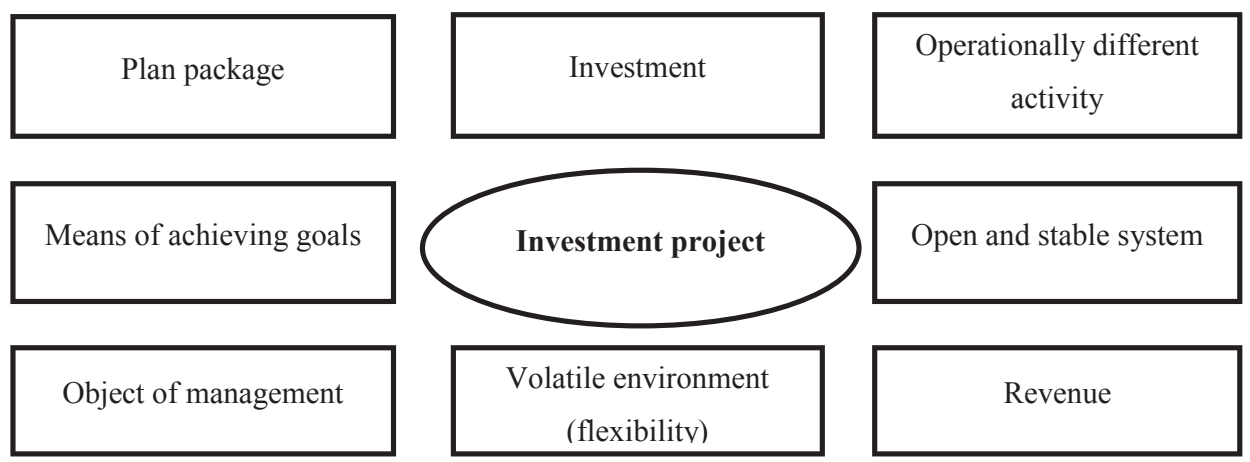

Fig. 3. Pattern of investment project

The implementation of capital investments from the Moscow city budget is carried out in accordance with the Moscow City Address Investment Program. The Address Investment Program is a document that establishes the distribution of the budgetary allocations for the implementation of investment projects for the construction, reconstruction, technical re-equipment of capital construction facilities in the city of Moscow for the next financial year and the planned period for the budget allocations for the implementation of investment projects in the city of Moscow within the arranged state programs and non-program expenses [4].

Urban development is the dominant form of spatial development of the city. Urban development is understood as the activity of public authorities, municipal bodies, legal entities and individuals in the field of architectural development of territories, taking into account the interests of public, state and civil interests, as well as national, historical, 
cultural, ecological, natural and other specific features of exact territories [5]. Urban planning activity assumes creation of favorable conditions of residing of the population with use of urban planning means.

The majority of municipal target programs and investment projects are implemented through urban development, so the planning and development of the territory is formed, the location of housing construction, urban and social facilities, transport and engineering communications is optimized in accordance with the zoning of the territory. The cityscape is being created and the state of the urban environment is improving.

In addition to the principles of harmonious development of the city, urban development must ensure the implementation of state, public and private interests [6].

State interests in the field of urban development are to ensure conditions for the sustainable development of settlements and inter-settlement territories, the functioning of state systems of engineering and transport infrastructure, conservation of natural resources, protection of historical, cultural and natural heritage sites.

Public interests in the field of urban development are to provide favorable living conditions, limit the harmful impact of economic and other activities on the environment, improve the environmental situation, develop the engineering, transport and social infrastructures of settlements.

Private interests in the field of urban development are the interests of citizens and legal entities, that occur in the result of the urban development.

State, public and private interests in the field of urban development are ensured by meeting the requirements of state town planning standards and rules with appropriate control. The coordination of state and public interests in the field of urban development is provided by state authorities and municipal government in accordance with the law [7].

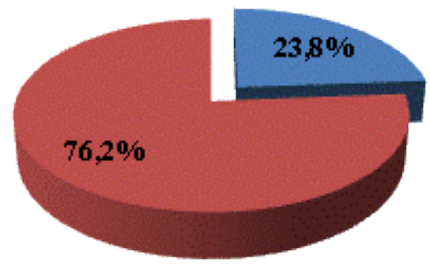

\section{Total housing stock of the city (as of the date 01. 07. 2017) is 278.4 million sculare meters, including: \\ $-238 \% \mathrm{good}$ and satisfactory condition (dilapidation is no more than $40 \%$ ) - 166.3 million. $\mathrm{ma}^{2}$ \\ $76.2 \%$ unsatisfactory and dilapidated condition (dilapidation is $41 \%$ and more) - 52.1 ridlion. $\mathrm{m}^{2}$}

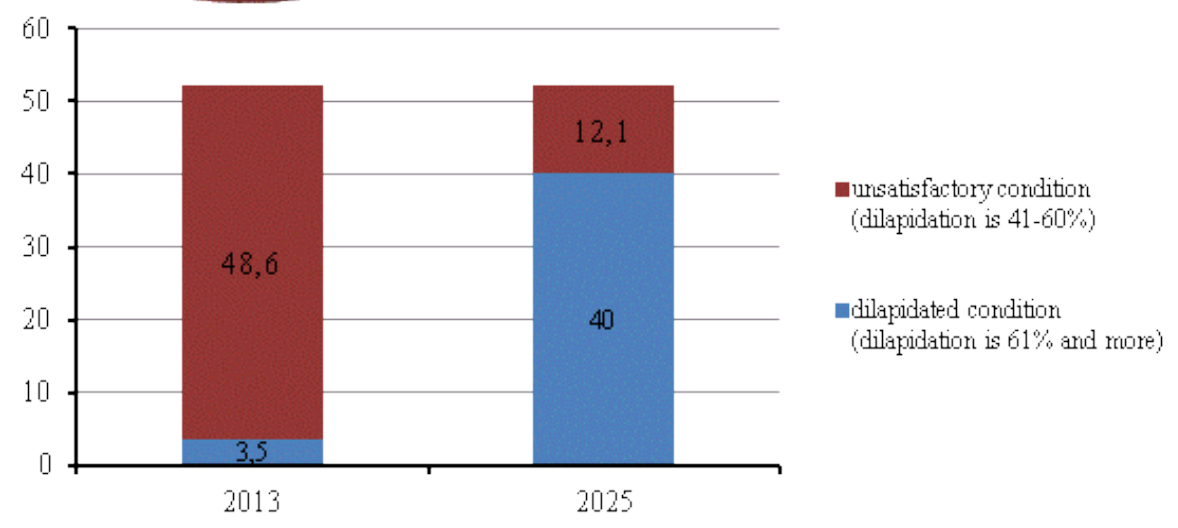

Fig. 4. Current state and forecast of housing funds in Moscow

However, urban development of the territories is necessary not only to ensure the realization of the interests of citizens and the state, but also for an objective reason dilapidation of the housing funds. The dilapidation of the houses gradually leads them to a state of emergency. This problem is typical for the entire territory of the Russian Federation, and it is considered to be the main cause of high prices for housing. In Moscow, 
in order to solve this problem, there is a housebreaking program for houses of the first period of industrial construction, which is now coming to an end and a large-scale renovation program is gaining momentum. However, a fairly high rate of construction is required in order to tackle this question, taking into account the need to maintain a high level of housing per 1 person.

There are houses in the housing funds of Moscow, which major repairs are not advisable, due to the non-conformity of constructions with the modern requirements for housing (multi-storey houses with wooden ceilings, houses of the first period of industrial purpose). According to the Recorder of deeds by 2017, the residential area of such houses was 10 million square meters. Taking into account the standards for resettlement and other needs of the city for solving citywide tasks, these dilapidated funds must be compensated with a coefficient of 1.5, which indicates the need to build in Moscow 3 million square meters of housing per year. Until now, it was complicated to implement such construction volumes in the territory of Moscow, which encouraged to utilize free sites and expand the boundaries of the city [8].

\section{Results}

The basis for ensuring the integrated development of the city's territory is the allocation of land to investors with pre-determined technical and economic indicators of the planned development and functional purpose in accordance with the town planning regulations and the master layout plan.

Conditions for concluding an investment contract and allocating a land plot for an investment project (separation of costs for engineering support of buildings, encumbrances, concomitant development of social infrastructure facilities, etc.), as well as technical and economic pattern of development are considered at the Urban Planning and Land Commission of the City of Moscow. Within this commission, among other things, an analysis of existing investment contracts is carried out, a decision is made as to whether further implementation of such projects is advisable.

At the present moment, ensuring the conditions for the formation and development of entrepreneurship, it is necessary at the new stage of economic reforms to proceed to solving the housing problem for broader categories of citizens: young families, social workers, doctors, teachers, scientists, engineers. Moreover, there should be taken measures aimed at putting more affordable housing into operation, as well as significantly expanding the possibilities for residential lease. A number of regions have initiated pilot projects, on the basis of which various forms of public-private partnership are being carried out to ensure the functioning and sustainable development of the market for residential and commercial leasing and sales of living space, that has been built on the city budget money.

The project of renovation of housing funds in Moscow is a major example of urban development. Such an ambitious program for the development of built-up areas has its own peculiarities in terms of setting new multiple objectives. Apparently, the city budget is not able to finance this project independently and fully, the feasibility of which depends on the cooperation of private investors and city authorities.

\section{Discussions}

Moscow administration plans to independently set the parameters and volumes of new construction, select contractors through competitive procedures and monitor the process through a specially created State Renovation Fund. The city administration plans to abandon the involvement of private sector and investment funds, providing funding through 
the city budget in order to fully control the situation at the initial stage of renovation. At the start of the program, the mayor's office estimated the implementation period of the program for $10-15$ years.

Despite the fact that most of Moscow's population supported the project, some experts expressed their concerns, voicing the following comments:

- Taking into account the experience of the previous demolition program for old houses under the Moscow package and private developers, the population has densified more than 3 times, with all the consequences: a heavy burden on the social and transport infrastructure, that will lead, for example, to electric "blackouts", colossal queues in kindergartens, schools and heavy traffic jams.

- According to the estimation of Greenpeace, the areas, which are going to be renovated, will lose up to $25 \%$ of green spaces, where there are especially ecologically effective zones that clean the city air.

- The expected increase in the supply of affordable housing next to the metro may lead to a price dumping and freezing of interest in secondary housing.

- The owners of mortgage apartments in five-story buildings are especially exposed to find themselves in a legal void.

\section{Conclusion}

Attraction of extrabudgetary funding, in order to develop urban planning environment of a city, plays a significant role in taking such decisions. Therefore, it results in necessity to create a favorable investment climate and economic conditions, that will encourage investors to cooperate with municipal authorities in order to accomplish the social tasks.

\section{References}

1. V.V. Gluhov, I.V. Ilin, Lecture Notes in Computer Science, 8638, pp 509- 518, (2014) DOi-10.1007/978-3-319-10353-2_46

2. V.I. Churkin, O.V. Kalinina, Estimation of excess burden of labor taxation in Russia, Actual Problems of Economics, Vol 184, IS 10, pp 278- 282 (2016)

3. N. Safronova, E. Nezhnikova, A. Kolhidov MATEC Web of Conferences 10608024. (2017) doi:10.1051/matecconf/201710608024

4. R. Golov, V. Shilov, S. Silantiev ASEE International Forum, Columbus, Ohio. June 28, 2017. Paper ID \#20766

5. M. Tibon, A. Borboni, M. Mor, D. Pomi 2011 Proceedings of the Institution of Mechanical Engineers. Part I: Journal of Systems and Control Engineering 225(3) 443-451

6. N. Harmathy, J. Kontra, V. Murgul, Z. Magyar, Advances in Intelligent Systems and Computing, Vol. 692, pp. 563 - 576 (2018) DOi- 10.1007/978-3-319-70987-1_60

7. F. Aggogeri, A.Avanzini, A. Borboni S. Pandini International Journal of Automation Technology 11(2) pp 311-321 (2017)

8. N. Harmathy, V. Murgul, Procedia Engineering, Vol. 165, pp. 1845 - 1852 (2016) DOi- 10.1016/j.proeng.2016.11.932 